\title{
ONE'S SELF-STRUCTURE RELATES TO THE CONTENT OF UTTERANCES ABOUT OTHERS
}

\author{
Nina N. Yuditseva \\ Moscow State University of Psychology \& Education, Russian Federation \\ E-mail: ninayudits@yandex.ru
}

\begin{abstract}
Embodiment and inter-subjectivity underlie one's subjectivity in Husserl's view. Based in Russian intuitivism Husserl's adherent Losskij has offered phenomenological opposition: one's act of distinguishing (mine ness) - common perception content given from both kinds of access which Overgaard identified as felt and perceived (given ness). The paper considers the self-other perspective-taking in order to reveal its psychodynamic relevance. One's disposition towards Big Two drives (ego-communion) specifies self-other differentiation. The Zondy test was used in the experiment.

The Correspondence analysis of participants' disposition towards BT drives and three arrays of utterances (all, about others, about oneself) made obvious the impact of one's disposition upon the distribution of the self-other utterances in the first two arrays. Additionally, in the aggregate of utterances about others, one's disposition also significantly correlates with the choice of the utterance type about others. Thus, one's disposition moderates the utterance content about other people.
\end{abstract}

Keywords: embodied cognition, phenomenological psychology, Jungian psychoanalysis, Russian intuitivism, self-structure.

\section{Introduction}

The training of orphan teenagers from both boarding school and penitentiary institutions towards self-dependent life was the part of my work for a long time. Training of social skills didn't solve their problem. They are characterized by some particularities. Without intimate people a lot of orphan teenagers have no a foothold. Being not aware its personal choice existence most of them were not agent of its life. Part of them is redundantly susceptible towards group pressure and stereotypes. Notwithstanding varied sense of agency, many of them are not oriented towards their communication partner. There can be pragmatic use of others (people are relevant so far as they have something that may be useful to me) or negative communication (self-assertion by humiliating others; or leaving others in a difficult situation and so on). Quite predictably, this orientation is on the increase in the subculture of penitentiary institutions, cultivating disregard for others. The orientation underlies impersonal, changeable opinion about others which is the basis for self-justification even when one's fault is obvious. The main problem was to promote them in self-separation from 
OF PSYCHOLOGY

IN THE $21^{\text {st }}$ CENTURY Vol. 12, No. 2, 2018

criminal subculture with which they had been identified. Self-dependency implies the growth of one's agency and active orientation to the others at the same time.

The questions of one's self origin and its contribution to perspective-taking of the others and utterances about them had required study. Indeed, we don't know the source of one's perspectivetaking which a posteriori divided on taken from the first, the second and the third person. The sense of agency is traditionally linked with the self and one's internal and external existence either an agent or an object for the others accordingly. It is their interrelation that presented interest.

\section{Background of Research}

The origin of self, its contribution to the perspective-taking of oneself and others is both a philosophical and psychological issue. Since the Bolshevik Revolution, Russian philosophy has been developing along two main directions. In Soviet and post-Soviet Russia scholars had to stick to dialectical materialism. Based on Karl Marx' approach to consciousness, examples of the subjectivity concept include theories of mindset (Uznadze, 1966), hierarchy of subjective needs (Bozhovich, 1968), the I phenomenon (Mikhaijlov, 1976) and subjectivity (Slobodchikov \& Isaev, 2000). This trend seeking to reveal the origin of the consciousness self-structure can hardly be considered productive. Both prioritizing the "intrinsic" or "extrinsic" factor and the very opposition ${ }^{1}$ would seem incorrect according to modern Husserl's adherents. Merleau-Ponty urged to reconsider the very opposition, and to search for a dimension that is beyond both objectivism and subjectivism (Mascolo, 2017; Muller \& Runions, 2003; Rowlands, 2010; Zahavi, 2010).

Other mode of thinking is represented by European-Russian phenomenological school of thought including epistemologists S. Frank and N. Losskij ${ }^{2}$. Their theory of genesis of knowledge proves that cognition is not independent of being; on the contrary it forms a part of the latter. In other words, for cognition to start, one must exist first (Frank, 1997). The body is an external object, nearest to the self, and an inseparable part of being, through which other external objects are likewise given to the person in the subconscious. Losskij has offered phenomenological opposition: one's act of distinguishing - all perception content, including felt and perceived ${ }^{3}$.

From this standpoint, the self-structure of consciousness is a constituent of the body ${ }^{4}$. Associated with an effort and attention, one's act of distinguishing is comprehended as inherent; he is an agent with regard to it (Losskij, 1991). The transcendental environment already exists and is given to one via cognition (Stavtsev, 2001). External objects exist there outside of individual consciousness. Sensation (sensory experience) also has an objective status. It is given experience which is not "my subjective state of consciousness" (Molchanov, 2010). So one can directly behold an object ${ }^{5}$ as it exists in reality (Vernov, 1999). One's cognizing activity consists in free choice of perception content to identify. Accordingly, the act of identifying other people may be driven by one's embodied activity (mine) or the content of the object identified (given), or by both (Losskij, 1991).

How is content of perception ${ }^{\mathrm{i}}$ transformed into conscious self-utterances and comments on others? While the latter are limited by the given content, the self- utterance permeates into both parts of the mine - given opposition. The first conclusion to be drawn is that self-utterance and

1 «I argue that psychological knowledge arises neither from within (subjectively) nor from without (objectively), but instead from between (intersubjectively). To understand what it means to be a person, we must abandon the false distinction between objectivity and subjectivity, and embrace an epistemology based on intersubjectivity» (Mascolo, 2017).

2 Russian intuitivism is a branch of phenomenology that considers man as self-cognizing existence and his body as external object (Losskij, 1991). Being proponents of non-revolutionary transformation of Russia, they were deported in 1922 and were free to deal with the concept of the self-structure and issues of religious philosophy. Although their unknown self-concept nowadays fills the embodied self, it has never been accepted by national psychologists.

3 "Perceive" and "feel" are different kinds of access. "I may perceive another's sadness - it may be visible in her facial expression, for example - but I feel, and do not perceive, my own sadness" (Overgaard, 2010).

4 The experience of the body, the lived body, may be regarded as the first and most fundamental manifestation of the phenomenal or minimal self. Our self in its most basic and minimal form is thus essentially a bodily self (Gallagher, 2000; Northoff, 2013; Zahavi, 2009).

5 Both the object and sensation are given to an individual as external. Thereby an object of cognition is considered by Losskij to be an implicit undifferentiated unity of an object and individual sensation. 
utterance about others do not coincide with components of contemplative knowledge. Second, the self-structure underlies the perspective-taking of others only. Herewith the self-structure can be differentiated or non-differentiated. With the latter, one's utterance about others is supposed to be self-related, because the content includes his or her intention. With the former, one's utterance about others is not self-related. Third, way of the self-structuring underlies one's intention to perception. Such interpretation leads to a new understanding of the essence of personal consciousness (i.e. self) as transpersonal non-sensory intention to perception content to identify.

The self is analyzed using psychodynamic Jungian trend seeking the origin of the self ${ }^{6}$ as objective structure of one's psyche. Yung (non Freud) with Frank think that one's consciousness centre (Yung, 1996) or structure (Frank, 1997) is defined by the disposition towards internal (i.e. ego) and external (i.e. communion) factor.

\section{Research Focus}

It was believed that the structure of one's ego-community drives underlie identification of perception content as self-related and others-related (spontaneous perspective-taking) and the utterance content ${ }^{7}$ about others. Since disposition towards ego-communion drives presupposes expanding/reducing/ ego drives and search/avoidance/of new contacts, the Zondy test was used in the experiment to determine the disposition of the participants.

Present research has tested correspondence existence between nonverbal participants' disposition towards Big Two drives and utterance arrays (about oneself, about others, all). A Correspondence analysis was expected to verify whether the self-other identification relates to participants' disposition towards BT drives.

\section{Research Methodology}

\section{General Background}

To detect participants' disposition towards Big Two drives was used the method of experimental diagnostics of drives. The comparison of the psychodynamic self with that in Russian intuitivism ${ }^{\mathrm{ii}}$ is required to use Zondy test.

The obtained preferences are classified as zero, positive, negative and ambivalent. The combination of zero values for both factors $(\mathrm{k} \& \mathrm{~d})$ was interpreted as passive attitude to searching for and the substitute of contacts and absence of attention towards ego drives. The combination of positive values for both factors showed active attitude to contact searching and approval of ego drive expansion. If both values happened to be negative, it meant that the participants were reluctant to search for new contacts and had their ego drive suppressed. An ambivalent response for both factors proved flexibility in searching for contacts and expansion of ego drives.

Participants' utterances about themselves and about others were determined by the SidneySaks test of unfinished sentences (limited to the same themes and customized by the Behterev Psychoneurological Institute).

Whatever the theme, the utterances were not always about people. For content analysis of two

6 Neuroscience will remain unable to properly and clearly segregate experimental measures for the minimal self from those of our experience in general, e.g., experience of the world. Neuroscience trend seeking to reveal specific neuronal mechanism underlying of the self has principled limitation: all phenomenal features and experimental measures are always already "infected" by the self. The results from neuroscience clearly link the self with neuronal processes related to both intraindividual experiences and interindividual interaction. The requirement of maximal experimental and phenomenal specificity may here have reached its phenomenal limits. We may be forced to acknowledge that there may be principal limitations in what we can and cannot investigate experimentally when it comes to the minimal self. It may therefore occur predominantly in the unconscious mode rather than becoming conscious as such. The minimal self may thus be the subjective component of what Freud described as ego, the objective structure of our psyche. Future research will be needed to show the exact organization and structure of the minimal self in order to reveal its psychodynamic relevance (Northoff, 2013).

7 Agency and communion are basic dimensions for judgments of self, others and groups. These two basic dimensions for describing and judging persons and groups, called agency and communion, can be linked to a basic distinction in social information processing, namely, the perspective of self and the perspective of other people (Abele \& Wojciszke, 2007; Uchronski, 2008; Uchronski, Abele, \& Bruckmuller, 2013). 
utterance aggregates (about others and about self), all finished utterances were divided into five types: evaluative, report on others, report on itself, report on interaction, and report on irrespective action.

Finished utterances were analyzed within utterance aggregates (about others, about oneself", all utterances), along categories (evaluative, etc,) and for each sample (students of a boarding school with reduced intelligence, with preserved intelligence, all students and all graduates).

\section{Sample of Research}

206 teenage orphans at the age 14-19 at will took part in the research. The sample was divided in two parts. One ( $n=141$ students of a boarding school for orphans) included 75 participations with reduced intelligence and 66 participants with preserved intelligence. The second group included 65 boarding school graduates at age 18-19, of which 36 were with reduced intelligence. All 65 were technical school students. The latter took part in research to determine the impact of the social status in the self-structure and utterances about oneself and others. Students of a boarding school were engaged in the experiment to assess the role of the intelligence in the self-structure.

\section{Results of Research}

Pre-Reflective Disposition towards Big Two Drives in the Joint Sample of Graduates and Students of Boarding Schools

The existence of at least four dispositions towards Big Two drives was experimentally set. They were not equally represented in the overall sample.

All tabular data were divided into four quadrants.

- The top left quadrant turned out to be biggest (65.5\% participants).

- On contrary, the bottom right quadrant turned out to be the least (3\% of the participants).

- $15 \%$ of participants have turned out to be in the bottom left quadrant.

- The top right quadrant included $16.5 \%$ of participants.

Table 1. One's pre-reflective dispositions towards Big Two drives of graduates and students of boarding schools.

\begin{tabular}{|c|c|c|c|c|c|}
\hline \multirow{2}{*}{$\begin{array}{l}\text { Factor d } \\
\text { participants' } \\
\text { evasion / } \\
\text { search for new } \\
\text { contacts. }\end{array}$} & \multicolumn{4}{|c|}{ Factor k (participants' introjection/rejection of ego drives' expanding) } & \multirow{2}{*}{$\begin{array}{c}\text { Total sum } \\
\qquad \sum_{\%}\end{array}$} \\
\hline & $\begin{array}{l}\text { Rejection of } \\
\text { ego drives' } \\
\text { expanding }\end{array}$ & $\begin{array}{l}\text { Disregard } \\
\text { towards ego } \\
\text { drives }\end{array}$ & $\begin{array}{l}\text { Introjection of ego } \\
\text { drives' expanding }\end{array}$ & $\begin{array}{l}\text { Rejection \& } \\
\text { introjection } \\
\text { interchange }\end{array}$ & \\
\hline $\begin{array}{l}\text { Evasion of new } \\
\text { contacts and } \\
\text { theirs change. }\end{array}$ & $\begin{array}{l}\text { No. } 1-30.1 \% \\
62\end{array}$ & $\begin{array}{l}\text { No. } 5-13.6 \% \\
28\end{array}$ & $\begin{array}{l}\text { No. } 9- \\
2.4 \% \\
5\end{array}$ & $\begin{array}{l}\text { No. } 13- \\
6.3 \% \\
13\end{array}$ & $\sum_{52.4}=$ \\
\hline $\begin{array}{l}\text { Inactivity } \\
\text { regarding } \\
\text { contacts and } \\
\text { theirs change. }\end{array}$ & $\begin{array}{l}\text { No. } 2 \text { - } \\
12.6 \% \\
26\end{array}$ & $\begin{array}{l}\text { No. } 6- \\
9.2 \% \\
19\end{array}$ & $\begin{array}{l}\text { No. } 10- \\
3.9 \% \\
8\end{array}$ & $\begin{array}{l}\text { No. } 14- \\
3.9 \% \\
8\end{array}$ & $\Sigma=29.6$ \\
\hline $\begin{array}{l}\text { Search for new } \\
\text { contacts, their } \\
\text { change. }\end{array}$ & $\begin{array}{l}\text { No. } 3- \\
6.8 \% \\
14\end{array}$ & $\begin{array}{l}\text { No. } 7 \text { - } \\
2.4 \% \\
5\end{array}$ & $\begin{array}{l}\text { No. } 11 \text { - } \\
1.5 \% \\
3\end{array}$ & $\begin{array}{l}\text { No. } 15- \\
0.5 \% \\
1\end{array}$ & $\sum=11.2$ \\
\hline $\begin{array}{l}\text { Interchange of } \\
\text { evasion and } \\
\text { search for new } \\
\text { contacts }\end{array}$ & $\begin{array}{l}\text { No. } 4- \\
1.9 \% \\
4\end{array}$ & $\begin{array}{l}\text { No. } 8- \\
3.9 \% \\
8\end{array}$ & $\begin{array}{l}\text { No. } 12 \text { - } \\
0\end{array}$ & $\begin{array}{l}\text { No. } 16 \text { - } \\
1 \% \\
2\end{array}$ & $\Sigma=6.8$ \\
\hline$\Sigma$ & $\Sigma=51.4 \%$ & $\Sigma=29.1 \%$ & $\Sigma=7.8 \%$ & $\Sigma=11.7 \%$ & 100 \\
\hline
\end{tabular}


The table shows that two-thirds of the participants (65.5\%) disregard or suppress ego drives activity of the participants. The disposition was marked as impersonal. As may be seen from their projective pictures of the tree, these participants cannot protect themselves against influence of other people around them, i.e. a company of peers. It did not depend on the social status ( $64.9 \%$ of students and $66.15 \%$ of graduates). In penitentiary institutions the disposition lobe reduces to $50 \%$.

Only $3 \%$ of the participants approved ego drives, were active in their realization and search for new contacts. The disposition was marked as self-determined. The latter remains the same $3.9 \%$ in penitentiary institutions.

$15 \%$ of participants have turned out to be active in search and change of contacts, alongside with disregard or suppression of ego drives. Their projective image of the tree shows the teenagers to be often self-contradictory. These participants communicate more actively with others to the detriment of realization of their ego drives. The disposition was marked as communicative. It doesn't exceed $19 \%$ in penitentiary institutions. The disposition was mainly typical of students with reduced intelligence.

$16.5 \%$ of participants were characterized by alternating approval/rejection of ego drives together with inactive search or evasion of new contacts. It makes one's ego drives dominating over the contacts. The disposition was defined as self-centered. It reaches $27 \%$ in penitentiary institutions.

The students with preserved intelligence, characterized mainly by the impersonal disposition (68.6\%), demonstrated the most depressive and inefficient social standpoint. As for those with reduced intelligence, they, on the contrary, to a greater extent (24\% against $8.9 \%$ with preserved intellect) seemed to possess a communicative disposition, what is more efficient for integration into the adult community.

\section{Comparison of Utterances about Themselves \& Others Made by Graduates and Students of Boarding Schools}

Whatever the theme, out of five possible types of utterance the students of boarding schools didn't prefer reports about themselves or others. Irrespective of their intelligence, they produced report on irrespective action in aggregate of self-related sentences and evaluative reports in array of sentences about others.

As for the graduates, in sentences aggregate about themselves, they reported on themselves 1.4 times more often than students spoke on irrespective actions. In sentences aggregate about others, the graduates used the report on others proper 1.5 times more often than students.

Probably, the decreased impact of teachers and peers makes the graduates of boarding schools more active towards their own life. The question if the difference is significant requires further investigation.

\section{Correspondence Analysis of Utterances about Oneself and Others with Disposition towards Big} Two Drives

Data of both tests were compared, with the use of Correspondence analysis to verify whether one's disposition towards Big Two drives underlies the choice utterances within aggregates (about others, about oneself, and all utterances). One's disposition towards Big Two drives was found to be significantly correlated $(p \leq .1)$ with the distribution of five utterance types within the whole array. The established difference was been fully confirmed in the utterance array about others $(p \leq .05)$.

The participants of different dispositions significantly diverged in the choice of utterance types in the whole array and array about others. Moreover, in array of utterances about others one's choice of the utterance type significantly correlated with disposition towards BT drives (see next paragraph). This means that one's pre-reflective disposition (i.e. one's agency) can be traced throughout a scope of conscious utterances. The main conclusion is one's pre-reflective disposition impacts on spontaneous perspective-taking of the others and comment content about them in the sample of orphan teenagers from both boarding school and penitentiary institutions.

Based on this method we have built an expanse of utterances about self and others, so that the 
OF PSYCHOLOGY IN THE $21^{\text {st }}$ CENTURY Vol. 12, No. 2, 2018

68

positive dimension of each axis correlates with various values of self-presence (axis $\mathrm{X}$ ) and -presence of others (axis Y). On the contrary, the negative dimension refers to the absence of self and others in the expanse of conscious utterances (Figure 1).

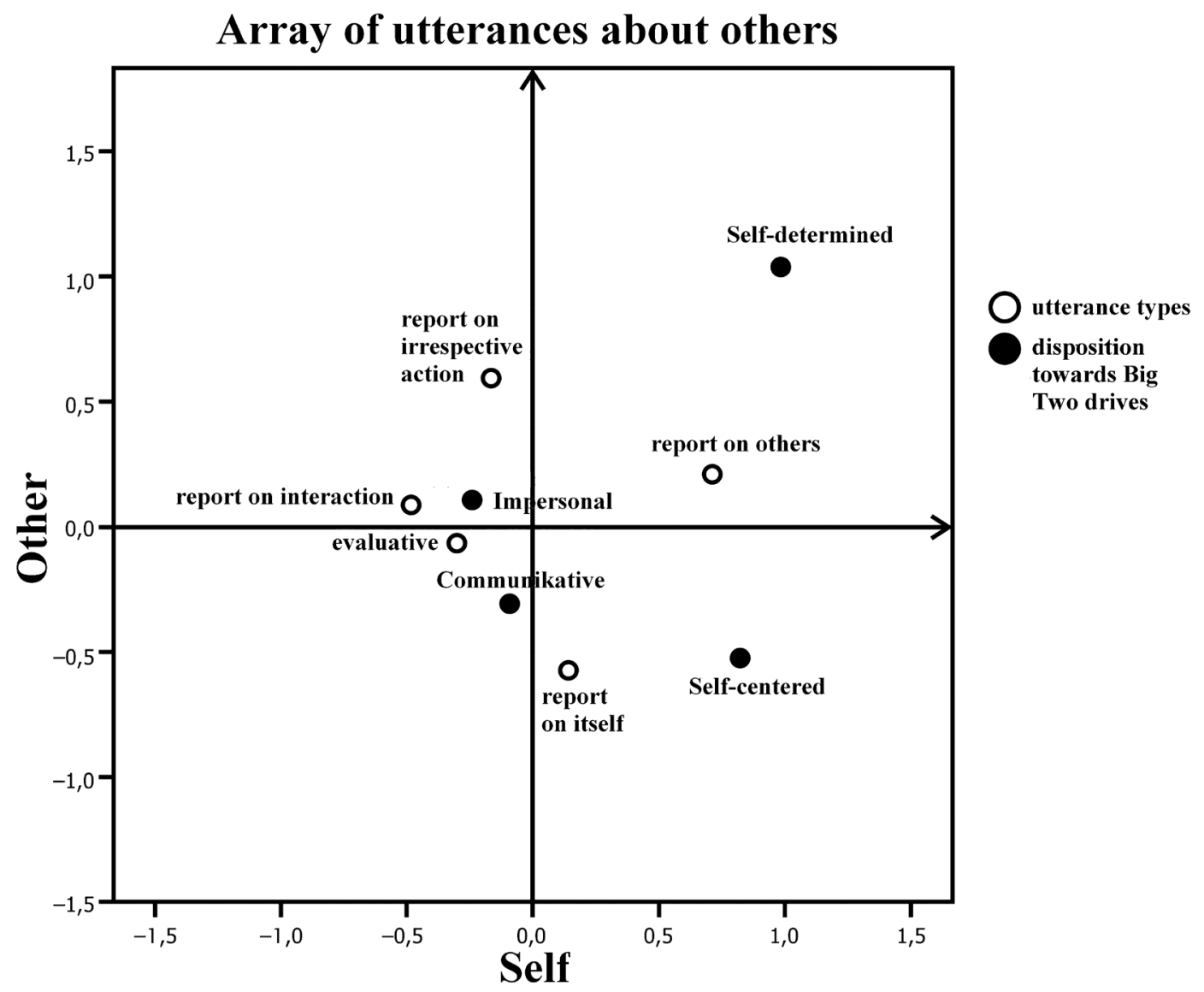

Figure 1. For the analysis of the array of utterances about others.

This model has brought together all found dispositions (black points on the Chart) and various types of utterances (black circles on the Chart). The distance between the former and the latter demonstrates frequency of the choice of the utterance type by participants with different disposition. To establish the type-disposition correlation we used the $\chi^{2}$ criterion. The same distance to the black point means the same frequency of the utterance type.

The model has enabled us to describe one's disposition as spontaneous self-identification and distinguishing others. Thus, some important conclusions can be made at this point.

- The location in different expanse quadrants has highlighted that one's disposition underlies instinctive self-others identification (or perspective-taking).

- Three dispositions (i.e. varied one's agency) are located close to one another and are opposed to the self-determined disposition. They underlie non-differentiated perspective-taking of other: not self-others, not self-not others or self-not others. The cohesion self-other content makes one's perspective-taking of other self-related. On contrary the self-determined disposition promotes non-self-related perspective-taking of other.

- Surprisingly is that in spite of one's active search for new contacts the communicative disposition does not promote one's expected attention to others (not self- not others) as may have been supposed. So, one's perspective-taking of other is likely to be driven by circumstances and body needs, rather than agential motives or interests of other people. The impersonal disposition, in spite of inactivity and 
contact evasion, does not necessarily cause (as might have been expected) disregard for other people (not self- others). However, one's perspective-taking of others in this case will likely be confined to peers group evaluation.

Predictably related with disregard for other people's interests, the self-centered disposition underlies the perspective-taking of other predominantly for one's own needs (self-not others).

- Likewise, in the aggregate of utterances about others, disposition also significantly correlates with the choice of the utterance type. To establish relevant differences, a share equality test was used (for normal distribution; the significance level being .05). It means that one's choice of the utterance type is related to the disposition towards base drives. One's agency is the source of perspective-taking of the others and comment content about them.

Communicative and self-centered dispositions of orphan teenagers underlie common for them "not other" perspective-taking of the others (Figure 1). While cumulative lobe of the dispositions in boarding school was $31.5 \%$ in penitentiary institutions it already reached $46 \%$. It is "not other" perspective-taking that underlies criminal relationship: "when have finished the deal, kill the accomplice!"

\section{Choice of the Utterances Type by Participants with Different Disposition towards Big Two Drives in Sets of Utterance about Others}

The content analysis revealed frequency of one's choice of the utterance type with regard to one's disposition. To establish relevant differences, a share equality test was used (for normal distribution; the significance level being.05). Predictably in the array of utterances "about oneself", there seemed to be no significant difference in the utterance types of participants with various dispositions.

In the array of utterances "about others", all dispositions significantly correlated with various types of utterances $(p \leq .05)$. For percent distribution of utterance types with various dispositions, see Table 3. Therefore, in this aggregate, one's disposition underlies the perspective-taking (see previous paragraph) and the content of utterances about others. The latter is self-related and should be interpreted within the self-structure.

Table 2. The utterance choice in the array "about others" by participants of various dispositions.

\begin{tabular}{|c|c|c|c|c|c|}
\hline \multirow{3}{*}{$\begin{array}{l}\text { Disposition towards } \\
\text { Big Two drives }\end{array}$} & \multicolumn{5}{|c|}{ Utterances type } \\
\hline & $\begin{array}{l}\text { Evaluative } \\
\text { report/ }\end{array}$ & $\begin{array}{l}\text { Report on } \\
\text { interaction }\end{array}$ & $\begin{array}{l}\text { Report on } \\
\text { others }\end{array}$ & $\begin{array}{l}\text { Report on } \\
\text { oneself }\end{array}$ & $\begin{array}{c}\text { Report on } \\
\text { actions }\end{array}$ \\
\hline & A & B & C & D & $E$ \\
\hline \multirow[t]{2}{*}{ Impersonal } & $28.0 \%$ & $19.6 \%$ & $18.6 \%$ & $19.8 \%$ & $14.0 \%$ \\
\hline & $>B C D E$ & $>E$ & & $>E$ & \\
\hline \multirow[t]{2}{*}{ Communicative } & $30.2 \%$ & $15.4 \%$ & $18.8 \%$ & $24.8 \%$ & $10.7 \%$ \\
\hline & $>B C E$ & & $>E$ & $>B C E$ & \\
\hline \multirow[t]{2}{*}{ Self-centered } & $19.5 \%$ & $10.3 \%$ & $32.2 \%$ & $31.0 \%$ & $6.9 \%$ \\
\hline & $>E$ & & $>\mathrm{BE}$ & $>B E$ & \\
\hline \multirow[t]{2}{*}{ Self-determined } & $18.6 \%$ & $9.3 \%$ & $41.9 \%$ & $11.6 \%$ & $18.6 \%$ \\
\hline & & & $>A B D E$ & & \\
\hline
\end{tabular}




\begin{tabular}{cccccc}
\hline & \multicolumn{5}{c}{ Utterances type } \\
\cline { 2 - 6 } $\begin{array}{c}\text { Disposition towards } \\
\text { Big Two drives }\end{array}$ & $\begin{array}{c}\text { Evaluative } \\
\text { report/ }\end{array}$ & $\begin{array}{c}\text { Report on } \\
\text { interaction }\end{array}$ & $\begin{array}{c}\text { Report on } \\
\text { others }\end{array}$ & $\begin{array}{c}\text { Report on } \\
\text { oneself }\end{array}$ & $\begin{array}{c}\text { Report on } \\
\text { actions }\end{array}$ \\
\cline { 2 - 6 } & A & B & C & D & E \\
\hline Total & $26.8 \%$ & $16.9 \%$ & $21.8 \%$ & $21.8 \%$ & $12.7 \%$ \\
\hline & $>$ B C D E & $>\mathrm{E}$ & $>\mathrm{BE}$ & $>\mathrm{BE}$ & \\
\hline
\end{tabular}

Note: In the Table, A stands for evaluative report, $B$ - report on interaction, $C$ - report on others, etc. $A>B C D E$ means that teenagers of an impersonal disposition prefer evaluation over all other types of report.

The impersonal disposition (not self-other) underlies group's perspective-taking of others. The participants preferred evaluations of the peer group. For two thirds of orphans, the peer community is vital. Their life after school goes on in half-closed subculture.

The communicative disposition (not self - not other) results in changeable circumstance-driven perspective-taking of others. When asked about other people, the participants equally preferred two types of utterances, evaluating and at first sight paradoxical report on itself.

The self -centered disposition (self- not other) underlies the perspective-takings that are consistent with each other. When asked about other people, self -oriented teenagers equally preferred utterances about others and about themselves. However, the former were cohesive with the last. For example: "My friends are my friends. I'll do what I want". Herewith these teenagers often happen to be in conflict with other people because they usually do not care what others think. A self -centered disposition was more common among students with preserved intellect, its share being significantly higher among teenage orphans in penitentiary institutions. Criminal subculture alongside with self-centered disposition promotes one's consciousness closure (Yuditseva, 2009).

The self-determined disposition causes self- and other- related contents to differentiate (selfother). When asked about other people, these participants definitely preferred an adequate utterance "about others". Thus, only 3\% orphan teenagers held the others to be self-determined agents and think about interaction with them. It was quite rare both among students and graduates. Moreover, it does not mean solely pro-social orientation, because the $3 \%$ may well include a leader of some kind.

\section{Discussion}

Findings confirmed the existence of pre-reflective minimal self-structure (Gallagher, 2008; Legrand, 2009; Losskij, 1991; Northoff, 2013;Frank, 1997; Yung, 1996, 1997; Zahavi, 2005). The results demonstrate the utterance content about others (mind process) is related to one's disposition towards BT drives (embodied activity). Different disposition promotes various modes of general perception differentiation into self-other content. The last is in keeping with Baldwin's theory of self-others content differentiation through embodied activity (Muller \& Runions, 2003).

The findings confirm empirical data about self-other differentiation underlying perspective taking (Demanet, Muhle-Karbe, Lynn, Blotenberg, \& Brass, 2013; Santiesteban et al., 2012; Sassenrath, Sassenberg, \& Scholl, 2014). Herewith both approved and rejected non-discriminated selfcontents make perspective-taking of other people and comments on them subjective, or self-related.

Being the source of perspective-taking of others the self-structure can exist within group relationship, body and self-consciousness (Pinku \& Tzelgov, 2006). Accordingly, self-agency is based on other agents and is therefore determined by a wide variety of internal and external cues (Synofzik, Vosgerau, \& Lindner, 2009) ${ }^{8}$. While the egocentric perspective is widely assumed to be natural and dominating, the most students and graduates of the boarding school (65.5\%) indeed

8 Additionally Synofzik considers it to be a pre-conceptual level of agency: "While differentiation of the sensory self-other content refers to a non-conceptual level of agency, perspective-taking is a conceptual level of judgment about agency"(Synofzik, Vosgerau, \& Newen, 2008). Instead Schpet separates one's consentience (self-other content differentiation) from self-agency (Shpet, 1994). Not being an effort, action or agent, one's consentience is a transpersonal self-others attitude underlying instinctive perspective-taking of the other. 
demonstrate the preference of peer group motives in perspective-taking of others. They are not Vol. 12, No. 2, 2018 oriented towards self-centered motives.

It could hardly have been expected that the one's reciprocal self-centered and communicative dispositions promoted the same "not-other" perspective-taking and paradoxical self-utterance in the others aggregate. This perspective presupposes one's either complete self-reliance or dependence on the physical condition. To say the least, these participants are not oriented towards their communication partner.

The findings appear to contradict Schimansky conclusion that social cognition is based on two independent processes - sense of agency and mentalizing ${ }^{9}$ (Schimansky, David, Rössler, \& Haker, 2010). With most participants, mentalizing depended on the sense of pre-reflective agency (one's disposition); only a few of them did not demonstrate the dependence. Only fully discriminated self-content ( $3 \%$ of our sample) enables one to transcend subjectivity in taking perspective of others.

The anticipated absence of correlation between one's dispositions (pre-reflective agency) with the choice of utterances about oneself has been experimentally confirmed. It can be explained by splitting of self into agential and given perspectives. The content of self- utterance seems to be affected by coordination of both perspectives related with non-sensory and sensory modes of selfexperience ${ }^{10}$ (intention, the thinking, sensation and emotion).

\section{Conclusions and Implications}

The results show the applicability of psychodynamic Jungian (non-Freud) trend in researching of pre-reflective self along with neuroscience one.

One's cognition of other person embodies four levels that are disposition towards BT drives (one's pre-reflective agency); self-structure non-differentiated (body-related, peer group-related, self-consciousness related) or differentiated; perspective-taking of other (embodied or disembodied), utterance content about other (self-related or none self-related). However, neither participants' actual self-structure, nor their utterances about others, facilitate them to grasp their problem of social integration.

- Being outside of self-awareness one's psychodynamic structure of ego-communion drives (non-sensory relation) however underlie the identification of perception content as self-related and others-generated (differentiated or non-differentiated);

- Non-differentiated self-others relationship underlie embodied perspective-takings of others and causes the content of utterances to be self-related; and vice versa differentiation leads to disembodied perspective taking with non-self-related content of utterances.

- The utterance content about others (mind process) is related to one's disposition towards ego-communion drives (embodied activity);

Self-utterance brings together both agential (intention) and given (felt, perceived) perspectives. Hence, self-perspective is likely related to perspective coordination, which is hierarchy of self-perception mode non-sensory (intuitive, thinking) or sensory (sensory and emotional one) according to Jungian categorization of psychological types. The question requires further investigation.

The findings can be successfully used for the training of orphan teenagers towards selfdependent choice of their future. The diagnostics of participants' self-structure (body-related, peer group-related, self-consciousness related) enables to grasp the motives of orphan group. Based in the latter you can build the future of group agent (corpse or coward) by means of series discussions demonstrating consequences of participants' choice at the fate building.

Possessing "not other" perspective the confined teenagers (46\%) disregard or have no interest towards others. Comfortable atmosphere during discussion and the skill of interact in group will promote participants' motivation towards interaction.

9 Cognitive capacity is to draw inferences about other peoples' beliefs or intentions.

10 These are to be coordinated via self-interpreting that is self-constructed and mediated by language. The language appears to be disembodied and is considered a form of action too. According to Clark (2006), language is a kind of self-constructed cognitive experience. When verbalizing thoughts, one creates structures that are themselves objects of perception, manipulation, and (further) thought. The inner language (i.e. the social language used as a tool for thinking and planning) modifies the sense of self (Clark, 2006). 
OF PSYCHOLOGY

IN THE $21^{\text {st }}$ CENTURY Vol. 12, No. 2, 2018

\section{References}

Abele, A. E., \& Wojciszke, B. (2007). Agency and communion from the perspective of self versus others. Journal of Personality and Social Psychology, 93 (5), 751-763. doi:10.1037/0022-3514.93.5.751.

Ado, P. (1991). Plotin ili prostota vzgljada [Plotinus or simplicity of sight]. Moskva: Greko-latinskij kabinet Ju.A.Shichalina.

Bozhovich, L. I. (1968). Lichnost'i ee formirovanie v detskom vozraste [One's personality and her shapping at baby's age]. Moskva.

Clark, A. (2006). Language, embodiment, and cognitive niche. Trends in Cognitive Sciences, 10 (8), 370-374. doi:10.1016/j.tics.2006.06.012.

Demanet, J., Muhle-Karbe, P. S., Lynn, M. T., Blotenberg, I., \& Brass, M. (2013). Power to the will: How exerting physical effort boosts the sense of agency. Cognition, 129 (3), 574-578. doi:10.1016/j.cognition.2013.08.020

Frank, S. L. (1997). Real'nost'i chelovek [Corporeal realm and person]. Moskva: Respublika.

Gallagher, S. (2000). Philosophical conceptions of the self: implications for cognitive science. Trends in Cognitive Sciences, 4 (1), 14-21.

Gallagher, S. (2008). Inference or interaction: social cognition without precursors. Philosophical Exploraitions, 11(3), 163-174.

Legrand, D. (2009). Two senses for 'givenness of consciousness'. Phenomenology and the Cognitive Sciences, 8 (1), 89-94. doi:10.1007/s11097-008-9116-0.

Losskij, N. O. (1991). Obosnovanie intuitivizma. In Izbrannoe [The substantiation of the intuitivism. In Selection]. Moskva: Izd-vo "Pravda".

Mascolo, M. (2017). How objectivity undermines the study o personhood: Toward an intersubjective epistemology for psychological science. New Ideas in Psychology, 44, 41-48. doi:10.1016/j.newideapsych.2016.11.005.

Mikhajlov, F. T. (1976). Zagadka chelovecheskogo YA [The riddle of human I]. Moskva: Politizdat.

Molchanov, V. I. (2010). Pozitsii i predposylki : teoriya znaniya N. O. Losskogo i fenomenologiya [Positions and assumptions /foundations/ of Losskij knowledge theory and phenomenology]. Logos, 5, 22-42.

Muller, U., \& Runions, K. (2003). The origins of understanding self and other: James Mark Baldwin's theory. Developmental Review, 23 (1), 29-54. doi:10.1016/S0273-2297(03)00004-2.

Northoff, G. (2013). Brain and self - a neurophilosophical account. Child and Adolescent Psychiatry and Mental Health, 7 (28). doi:doi:10.1186/1753-2000-7-28.

Overgaard, S. (2010). The problem of other minds. In S. Gallagher \& D. Schmicking (Eds.), Handbook of Phenomenology and Cognitive Science (pp. 255-268). The Netherlands: Springer.

Pinku, G., \& Tzelgov, J. (2006). Consciousness of the self (COS) and explicit knowledge. Consciousness and Cognition, 15 (4), 655-661. doi:doi 10.1016/j.concog.2005.10.001.

Rowlands, M. (2010). Consciousness. In Gallgher Shaun \& S. Daniel (Eds.), Handbook of Phenomenology and Cognitive Science (pp. 85-98). Dordrecht New York Heidelberg London: Springer.

Santiesteban, I., White, S., Cook, J., Gilbert, S. J., Heyes, C., \& Bird, G. (2012). Training social cognition: From imitation to Theory of Mind. Cognition, 122 (2), 228-235. doi:10.1016/j.cognition.2011.11.004.

Sassenrath, C., Sassenberg, K., \& Scholl, A. (2014). From a Distance ...: The Impact of Approach and Avoidance Motivational Orientation on Perspective Taking. Social Psychological and Personality Science, 5 (1), 18 26. doi:10.1177/1948550613486672.

Schimansky, J., David, N., Rössler, W., \& Haker, H. (2010). Sense of agency and mentalizing: dissociation of subdomains of social cognition in patients with schizophrenia. Psychiatry Research, 178 (1), 39-45. doi:10.1016/j.psychres.2010.04.002.

Synofzik, M., Vosgerau, G., \& Lindner, A. (2009). Me or not me - An optimal integration of agency cues? Consciousness and Cognition, 18 (4), 1065-1068.

Synofzik, M., Vosgerau, G., \& Newen, A. (2008). Beyond the comparator model: A multifactorial two-step account of agency. Consciousness and Cognition, 17 (1), 219-239. doi:10.1016/j.concog.2007.03.010. 
Uchronski, M. (2008). Agency and communion in spontaneous self-descriptions: Occurrence and situational malleability. European Journal of Social Psychology, 38 (7), 1093-1102. doi:10.1002/ejsp.563.

Uchronski, M., Abele, A. E., \& Bruckmuller, S. (2013). Empathic perspective taking and the situational malleability of the communal self-concept. Self and Identity, 12 (3), 238-258. doi:10.1080/15298868.2012.655896.

Zahavi, D. (2005). Subjectivity and selfhood: Investigating the first-person perspective. London: MIT Press.

Zahavi, D. (2009). Is the self a social construct? Inquiry-an Interdisciplinary Journal of Philosophy, 52 (6), 551573. doi:10.1080/00201740903377826.

Zahavi, D. (2010). Naturalized phenomenology. In Gallagher Shaun \& S. Daniel(Eds.), Handbook of Phenomenology and Cognitive Science (pp. 3-20). Dordrecht New York Heidelberg London: Springer.

Vernov, A. N. (1999). Problema aktivnosti sub"ekta poznaniya v intuitivizme N. O. Losskogo [The activity of perception agent at Losskij intuitivism]. Retrieved from http://www.dissercat.com/content/problemaaktivnosti-subekta-poznaniya-v-intuitivizme-n-o-losskogo

Zondi, L. (2005). Uchebnik ehksperimental'noj diagnostiki vlechenij [The experimental diagnostics of one's drive states]. Moskva: Kogito-TSentr.

Slobodchikov, V. I., \& Isaev, E. I. (2000). Psikhologiya razvitiya cheloveka: Razvitie sub"ektivnoj real'nosti v ontgeneze. In Osnovy psikhologicheskoj antropologii [The basises of the psychological anthropology] (pp. s.416). Moskva: Izdatel'stvo PSTGU.

Stavtsev, S. N. (2001). Fenomenologiya Gusserlya i russkij intuitivizm. Mezhdu metafizikoj i opytom [Gusserl phenomenology and Russian intuitivizm. Between metaphisics and experience ]. Retrieved from http:// anthropology.ru/ru/texts/stavtsev/metaexp_09.html

Uznadze, D. N. (1966). Psikhologicheskie issledovaniya [Psychological studies]. Moskva: Nauka.

Shpet, G. G. (1994). Filosofskie ehtyudy [Phylosofical essays]. Moskva: Izdatel'skaja gruppa "Progress".

Yuditseva, N. N. (2009). Otnosheniya v sisteme «ya- drugoj» u podrostkov-vospitannikov shkol-internatov i otbyvayushhikh nakazanie $\mathrm{v}$ mestakh lisheniya svobody [Perspective-taking of others by orphan-teehagers from boarding school and penitentiary institutions]. In L. F. Obukhova, E. G. Yudina, \& I. A. Korepanova (Eds.), Drugoe detstvo[Another childhood] (pp. 63-80). M: MGPPU.

Yung, K. G. (1996). Struktura psikhiki i protsess individuatsii [Self-structure and individuation process]. Rossiya Moskva: Nauka.

Yung, K. G. (1997). AION Issledovanie fenomenologii samosti [Study of phenomenology of the self]. Rossiya Moskva: Refl-buk.

i Thus, one's subconscious knowledge is gleaned from mine (acts of distinguishing, attention, acts of choice and so on) and given (sensory, psychic content or any other kind of experience) and "I". Mine content and " $I$ " may seem to have the same nature. However, «I» has neither spatial no temporal characteristics, unlike mine or given content. Being transpersonal social attitude (mine-given) "I" hardly has sensorial representation (Losskij, 1991). It is a transpersonal, non-sensible mine-given attitude or intention. It is not an agent. It is consentience. It is only self-interpretation that makes "I" unique. Consciousness, agent, "I" are completely different concepts, not to be substitute one for another (Shpet, 1994). A person is only a temporal carrier of this social transpersonal structure. According to Plotin, "the center of consciousness is the angle of vision and the perspective centre. For us, our "I" coincides with the starting point" (Ado, 1991).

While not being a condition of existence of one's contemplative consciousness, one's self-structure is a pre-requisite for the awareness of oneself as agent because of it underlie perspective-taking of others. A newborn child first exists as a separate object only for its parents but not for itself. The child holistically perceives the surrounding world and itself in the world, without separating the given experience from that of its own acts of choice, volition and psychic states. The child's holistic cognition first exists as uniform and is not correlated with that content. When spontaneous involuntary self-regulation of Big Two drives begins, the child's self-related content separates from others. Herewith reportable self-related experience includes " $I$ ", mine and given (perceived and felt) content. To some extent, the selfstructure provides for detachment of child's consciousness from that of the family, society. "I" is only the correlative subjective point in common consciousness (Losskij, 1991).

ii Comparison psychodynamic self with that in Russian intuitivism

Both self-concepts are described by the common $\mathrm{k}$ factor (introjection/rejection of ego drives) that is practically not subject to any changes. Whereas destiny analysis studies ego drives with regard to subconscious or conscious forms of drive implementation (factor p); intuitivism analyses ego drives taken in conjunction with one's contacts (factor d). Conditioned with Big Two drives, the self is described by respective factors $k$ and d. Factor d" that replaces " $p$ " indicates one's longing for contacts with others. The common factor $\mathrm{k}$ makes the self as the core of motivated cognition gravitated to the corresponding evolutionary form of ego existence based on $\mathrm{k}$ and $\mathrm{p}$ factors (Zondy, 2005). Being neither consequent nor universal the forms are characterized by various ways of perspective-taking of social context. 
OF PSYCHOLOGY

IN THE $21^{\text {st }}$ CENTURY

Vol. 12, No. 2, 2018

74
Destiny analysis (psychoanalysis)

\begin{tabular}{|c|c|}
\hline $\begin{array}{l}\text { Genesis of } \\
\text { one's self }\end{array}$ & $\begin{array}{l}\text { Based on unconscious family drives } \\
\text { sphere) under surrounding ambier } \\
\text { effects (super ego). }\end{array}$ \\
\hline Function & $\begin{array}{l}\text { The ego is a psychic mechanism } \\
\text { protecting against external threats ar } \\
\text { unconscious drives. }\end{array}$ \\
\hline Definition & $\begin{array}{l}\text { It organizes one's subconscious drives } \\
\text { and sensory perceptions. }\end{array}$ \\
\hline Difference & $\begin{array}{l}\text { 1. The ego is limited by the psychic } \\
\text { reality } \\
\text { 2. Origin is disposition towards drives } \\
\text { exist and to have }\end{array}$ \\
\hline $\begin{array}{l}\text { Described } \\
\text { by common } \\
\text { factor } k \text { and } \\
\text { different } \\
\text { factors }\end{array}$ & $\begin{array}{l}\frac{\text { Factor } k \text { (introjection/rejection of ego }}{\text { drives)/ }} \\
\text { Factor } p \text { (recognition/projection of } \\
\text { subconscious drives) }\end{array}$ \\
\hline
\end{tabular}

Received: November 29, 2018

factors
Conditioned by psychodynamic structure of egocommunion drives, i.e. one's disposition towards basic drives: ego and long for contacts.

Social cognition, for perspective-taking and designation of a subject.

It is one's transpersonal non-sensory intention to perception content to identify.

1. Proceeding from one's opposition of psychic contents the self is at the same time transpersonal intention.

2. Origin is disposition towards Big Two drives: ego and communion.

Factor $k$ (introjection/rejection of ego drives)/ Factor d avoidance (evasion)/searching for new contacts. 